\title{
Assessing the effectiveness of ethnomedicinal products on banana weevils using REML
}

\author{
Bwogi Godfrey $^{1}$, Mwine Julius ${ }^{1}$, Jumba Francis ${ }^{1}$, Murongo Marius ${ }^{1}$, Grace Njeri Njoroge ${ }^{2}$, \\ Kabango Freddie ${ }^{3}$, Mutumba Nakulima Kyeswa Pross ${ }^{3}$ \\ ${ }^{1}$ Faculty of Agriculture, Uganda Martyrs University, P.O Box 5498 Kampala, Uganda \\ ${ }^{2}$ Faculty of Science, Jomo Kenyatta University of Science and Technology, P.O Box 62000 Nairobi, Kenya \\ ${ }^{3}$ Production Department, Ministry of Agriculture Animal Industry and Fisheries, P.O Box 634 Masaka District, Uganda
}

\section{Email address:}

gbwogi@umu.ac.ug (B. Godfrey), gnjoroge@fsc.jkuat.ac.ke (N. N. Grace), jumwi@umu.ac.ug (M. Julius), fjumba@umu.ac.ug (J. Francis), mmurongo@umu.ac.ug (M. Marius), kabangofreddie@hotmail.com (K. Fred), mutumbapros@yahoo.com (M. Pross)

\section{To cite this article:}

Bwogi Godfrey, Mwine Julius, Jumba Francis, Murongo Marius, Grace Njeri Njoroge, Kabango Freddie, Mutumba Nakulima Kyeswa Pross. Assessing the Effectiveness of Ethnomedicinal Products on Banana Weevils Using REML. Agriculture, Forestry and Fisheries.

Vol. 3, No. 5, 2014, pp. 420-426. doi: 10.11648/j.aff.20140305.25

\begin{abstract}
This study investigated the effect of applying selected banana pest control treatments on management of banana weevils. The data was collected on 283 banana plants picked at random; from 29 farmers selected using a snowball sampling technique. Treatments used were ethnomedicinal products, synthetic chemicals, cultural practices in plantation planted from suckers and those planted from tissue culture. Since data was spatially collected, it was analyzed using Restricted Maximum likelihood Estimator (REML). REML was used to estimate the PCI after a square root transformation. The statistical analysis indicated a significant difference between plantations where synthetic chemicals, clean planting materials (tissue culture), cultural practices and ethnomedicinal products were used. There was also significant variation resulting from different varieties grown. However, there was no significant variation resulting from the response of different varieties to the different treatments. Results also indicated that garden where the cleaning materials had been used had the least percentage of banana weevil infection. This study found out that there was no significant difference in damage caused by banana weevils in banana plantations where synthetic chemicals and ethnomedicinal extracts were applied. Thus given the results, the study concluded that ethnomedicinal products can be used by farmers to manage banana weevils. The study recommends that further studies should be carried out to assess efficacy of the identified potential plants with pesticidal properties under controlled experiment.
\end{abstract}

Keywords: Ethnomedicine, Restricted Maximum Likelihood, Percentage Coefficient of Infestation

\section{Introduction}

Banana form the main staple food in the Central, Western and Mt. Elgon regions of Uganda. They are also a cash crop to many smallholder farmers in the region. Food and Agricultural Organisation (FAO) [1] estimated per capita consumption of Matooke in Uganda at $243 \mathrm{~kg} /$ year. The total consumption is estimated by Spilsbury, Jagwe and Fernes [2] at 4,554,000 metric tons/year. Given the important position of banana in the diet of Ugandans, efforts to ensure sustainability and improved food production methods is priority especially managing soil fertility, pests and diseases [2]. Of recent, bananas are under threat from various pests and diseases. The pests include banana weevils and nematodes and the major diseases are Sigatoka, banana bacterial wilt (BBW) and panama wilt diseases (PWD). According to Bosch et al., [3] as cited by [2], banana weevils are one of the major pests that threaten the banana industry. Use of synthetic agro-chemicals to control banana weevils, can only offer short term remedy to the problem of pests but has failed to provide long term solution to the challenges. On the other hand, smallholder farmers cannot afford to pay for the high cost of imported agro-chemicals. In addition, prolonged use of synthetic agro-chemicals has resulted to resistant pests, health hazards to users and destruction of the non targeted natural enemies thus destabilizing the ecosystem [4]. Therefore, studies to elucidate the efficacy of the ethnomedicinal products were important. 


\subsection{Banana Weevils}

Banana weevils Cosmopolites sordidus belong to the Coleoptera species super family Curculionidae and are the most important pests for bananas [5]. They are nocturnal insects that are found mostly in banana plantations [6]. The most damaging stage of the pest is its larvae that tunnels through the stem, rhizome and pseudostem. Control of banana weevils varies from one farming system to another. According to Gold and Messien [5], commercial farmers are more likely to use synthetic chemicals; whereas resource poor, small scale farmers are more likely to use botanicals and cultural control methods [7].

\subsection{Use of Ethnomedicinal Products}

Over time, farmers have developed local knowledge and skills of controlling banana pests and diseases; but this knowledge has slowly been overshadowed with use of synthetic agro-chemicals. In the management of banana pests, farmers use remedial ethnomedicinal products composed of a number of plant species and targets several pest species in the field. According to $[8 ; 9]$, majority of peasant farmers in Sub Saharan Africa still depend on ethnomedicinal plants and traditional practices for both crop and livestock production. Food systems especially for small scale farmers are increasingly being threatened by outbreak of pests and diseases [9]. These pests and diseases are hard to control due to the high cost of agricultural inputs. This is compounded by the health hazards posed by these chemicals. Therefore, this necessitates urgent need to buildup reliable food production systems in developing countries, in Africa, where people are regularly faced with harsh environmental constraints of drought, pest outbreaks, a constant lack of agricultural inputs and limited financial means [7]. Berger [9] discussed need for smallholder farmers to embrace the theory of sustainable agriculture and self-reliance. Different aid organizations have tried to channel their help to small farmers in the tropics in order to facilitate use of resources, which are locally available and can be cheaply maintained [9]. The possibility of making raw extracts from plants growing in the neighborhoods, where the farmer lives, assists in ensuring self sufficiency and gives the farmers a cheap alternative to conventional synthetic pesticides which are often imported using foreign exchange. Large-scale production of natural pesticides could also provide an income for people in the countryside [9].

In Sub- Saharan Africa use of synthetics is still at its infancy. People have always been skeptical about using foreign chemicals on their farms. Smallholder farmers mostly rely on traditional knowledge to manage crop pests [7]. However, there is a knowledge gap on the effectiveness and productivity of many extracts used in pest and disease management. Therefore research in botanicals, which are effective on pests, is imperative.

Using herbs is staging a comeback and herbal renaissance is happening all over the globe [10]. Scientists have experimented on use of ethnomedicinal products to find their efficacy on banana weevils and other banana pests. Inyang and
Emossairue [11] explored the repellence of 13 plant species while Musabimaana [12] and Umeh, et al., [13] experimented on the use of neem leaves as mulch in banana weevil management with acceptable results. These studies affirmed the possibility of having active ingredients in plants that can act as an option in management of banana weevils.

This contributes to the objective of identifying, locating and documentation of those important plant products that can be used for pests and disease control in banana production. Over thirty ethnomedicinal species have been identified by farmers and are used on various crops and livestock pests [14].

Use of plant derived botanicals in crops, livestock and human health symbolises safety in contrast to the synthetic chemicals that are regarded as unsafe to human and environment [15]. Use of biopesticides is not only environmentally and ecologically friendly; but also gives better results than the traditional synthetic chemicals. Biopesticides have an array of properties including toxicity, repellence, antifeedance and control of insect regulatory mechanisms [16]. Therefore, smallholder farmers' relying on botanical products is not unfounded. However there is need to validate this knowledge. Some studies so far about traditional knowledge have been positive. On-farm studies in biopesticides indicated that they increased yields in pigeon peas by 20-30\% [16]. A vegetable research on the use of pencil tree was found effective in control of cabbage pests. This is evidence that botanicals can effectively manage and reduce pest population pressure to below economic significance in crop production $[14,16]$.

Research is an expensive venture that takes time and resources. Screening the pool of traditional knowledge can help in reducing on the cost of planning for efficacy trials. The study that aimed at finding out the extent to which ethnomedicinal products are used in the control of banana weevils was carried out in Masaka and Mpigi Districts. Ethnomedicinal extracts used were mainly from Tephoresia, Tobacco, Phytolaca, mixed with animal urine and ash. The study also explored the mode of preparation and application of ethnomedicinal products and the relative effectiveness of ethnomedicinal products on banana weevils in banana plantations where various pest control treatments are used. The assessment was carried using the Percentage Coefficient of Infestation (PCI) in plantations where the different pest control applications are use and on variety grown. A Restricted Maximum Likelihood Estimator (REML) which is a Generalized Linear Models (GLM) used in analyzing spatially collected data was employed. REML was used to compare the percentage coefficient of infestation of weevils in plantations where different treatments were applied i.e. where ethnomedicinal products were applied and where they are not.

\section{The Model Used}

\subsection{Residual Maximum Likelihood Estimator}

Residual Maximum Likelihood Estimator (REML) is used where Analysis of Variance (ANOVA) would have been used 
and has not; when the data is unbalanced, uncorrelated and has two or more sources of variation. The method was introduced by Patterson and Thompson [17] as cited by Welham [18]. REML is important in estimation of biased variance components produced by the ordinary Maximum likelihood estimators (MLE's). Since estimation of unbalanced designs is not possible, it therefore requires a robust maximum likelihood estimation model [18]. The model enables one to estimate the fixed and random effects. In this study, the banana pest control treatments were not randomized. They were purposively selected by the experimenter. If the experiment is repeated, the four pest control treatments must be used again and only the random errors are changed [19]. On the other hand, the varieties as treatment were randomly selected and the variance in the population of banana verities as treatments contributes to the total sum of squares [19]. In this study, the banana varieties most likely changed from farm to farm. Thus not only the errors were changeable, but also the banana variety random effects were changeable. Use of REML, which include an adjustment for the degrees of freedom, therefore, is employed in estimation of the fixed and random effects [17, $18]$.

\subsubsection{Equations of the Model}

The equation for model is as follows

$$
y=X^{\prime} r+Z^{\prime} u+e
$$

Where $u$ and $e$ are independent of each other.

- $y=$ vector of data (damage resulting from infestation of weevils)

- $r=$ unknown treatment effects of ethnomedicinal extracts with design ( $\mathrm{x}$ p) matrix $X$

- $u$ represent q random block effects with (n x q) design matrix $Z$ and $u \sim \mathrm{N}\left(0, \sigma_{b}^{2} I\right)$ - Independent effects with equal variance

- $\mathrm{e}=$ is vector of residual errors(noise ) with $\mathrm{e}=\mathrm{N}\left(0, \sigma^{2} I\right)$

According to Smith and Verbyla [20] REML partition the likelihood into two independent parts:-

$$
\text { 1. } y_{1}=L_{1}^{\prime} y_{1}=\text { fixed effects }
$$

2. $y_{2}=L_{2}^{\prime} y_{2}=$ relating to residual

$L_{1}=\mathrm{n} \times \mathrm{p}$ matrix of full column rank

$L_{2}=\mathrm{n} x[\mathrm{n}-\mathrm{p}]$ matrix of full column rank

$$
L_{1}^{\prime} X=I, L_{2}^{\prime} X=0
$$

Then:

$$
\left(\begin{array}{l}
y_{1} \\
y_{2}
\end{array}\right) \sim N\left(\left[\begin{array}{l}
\gamma \\
0
\end{array}\right], \sigma^{2},\left[\begin{array}{ll}
L_{1}^{\prime} H L_{1} & L_{1}^{\prime} H L_{2} \\
L_{2}^{\prime} H L_{1} & L_{2}^{\prime} H L_{2}
\end{array}\right]\right)
$$

This can be solved using equation

$$
l\left(\tau, \gamma, \delta^{2}, y\right)=l\left(\tau, \gamma, \frac{\sigma^{2} ; y_{1}}{y_{2}}\right)+l\left(\gamma, \sigma^{2}, y_{2}\right)
$$

The conditional distribution of $y_{1} / y_{2}$ has expected variance of:

$$
\left(y_{1} / y_{2}\right)=\gamma+L_{1} \mathrm{H} L_{2}\left(L_{1}^{\prime} H L_{2}\right)^{-1} y_{2}
$$

And variance:

$$
\operatorname{var}\left(y_{1} / y_{2}\right)=\sigma\left(L_{1}^{\prime} H L_{1}-L_{1}^{\prime} H L_{2}\left(H_{2}^{\prime} H l_{2}\right)^{-1} l_{2} H l_{1}\right)
$$

The fixed effects are solved using the equation:

$$
l_{1}=l\left(\tau, \gamma, \sigma ; \frac{y_{1}}{y_{2}}\right)
$$

Given that

$$
\begin{aligned}
\frac{\partial \ell}{\partial \mathrm{\tau}}= & X^{\prime} H^{-1} X\left(L_{1}^{\prime}(1-H P) y-\mathrm{T} / \sigma^{2}\right. \\
& \Rightarrow \hat{\mathrm{T}}=\left(L_{1}^{\prime}(1-H P) y\right. \\
\Rightarrow \hat{\mathrm{T}} & =\left(\mathrm{X}^{\prime} H^{-1} X\right)^{-1} X^{\prime} H^{-1} \mathrm{y}
\end{aligned}
$$

Where $\hat{\tau}$ depends on estimated variance of parameter through $\mathrm{H}$. That is to say:

$$
\operatorname{var}(\hat{\mathrm{T}})=\sigma^{2}\left(\mathrm{X}^{\prime} H^{-1} X\right)^{-1} r
$$

And then the random effects are derived by

$$
l_{2}=l\left(r \sigma^{2} ; \mathrm{y}_{2}\right)
$$

Since $y_{1}$ and $\tau$ are with same length, Smith and Verbyla [19].

\section{Materials and Methods}

\subsection{Area of Study}

The area under study, Masaka and Mpigi Districts, lies between $\mathrm{N} 00^{0} .0034, \mathrm{E} 032^{0} 0080$ and $\mathrm{S} 00^{0} 1891$, E $031^{0} .4447$ elevation is 1229 Above Sea Level(ASL). The mean annual rainfall is $1000 \mathrm{~mm}$ to $2200 \mathrm{~mm}$. The rains are spread in two seasons between March to May and August to November. The average annual temperatures range between $22.5^{\circ} \mathrm{C}$ to $27{ }^{\circ} \mathrm{C}$. The relative humidity is $80 \%$ to $95 \%$. The average rain days per year are 127 with an average 10.6 rain days/months. The climate is very favourable for the perennial crops especially banana and coffee. It is favourable for the multiplication of crop and animal pests and diseases.

\subsection{Methodology}

The relative effectiveness of the products was assessed using the Percentage Coefficient of Infestation (PCI) using data from 29 farmers who use either synthetic chemicals, ethnomedicinal extracts or rely on cultural practices only. The ethnomedicinal extracts used were mainly extracted from pepper (Capsicum frutencesis), tobacco (Nicotiana tabacum) and Mexican marigold (Tagetes erecta), Phyotolaca dodecandra, Tithonia diversifolia, Tephorosia vogelii, and Crassocephalum crepidioides. The most commonly used synthetic chemicals were Dusband and Carbofuran. Among the farmers who applied chemicals, 3 farmers applied chemicals on traps and among a group of farmers, who practiced cultural practices, 7 farmers used tissues culture planting materials. These were coded separately for analysis. 
Therefore, the numbers of farmers using different treatments were not equal and also the number of varieties from which the PCI was estimated was not the same. Data was collected on the percent of damage score on banana corms on at least 9 banana plants per plantation selected at random. Data was collected from a total of 283 banana plants, a number that was plausible to estimate variability using a multi stage sampling technique adapted from Ross [21]. Variety from which PCI was picked was also recorded. Percent coefficient of infestation (PCI) formula was based on Oginga and Bakyallire, [22] and Gold, Speijer and Rukazambaga [23]. The suggested model $\left(y=X^{\prime} r+Z^{\prime} u+e\right)$ was interested in estimating the mean percentage coefficient of infestation, $\mu$, from of the entire population of banana in the study area. The study also estimated the variation in percent coefficients of infestation expressed as $\sigma^{2}$.

Equation 1: REML Model 1

Assuming that the PCI, Y, is normally distributed

$$
\left(Y \sim N\left(0, \sigma^{2}\right)\right)
$$

The model can be expressed as:

Equation 2: REML model 2

$$
Y=X \gamma+Z u+\text { errors }
$$

Where: $Y=$ Response variable with vector $\left(y_{1}\right.$ to $\left.y_{n}\right)$ $\gamma=$ fixed unknown treatment effects with design matrix $(n *$ p) $X$

$u=$ random effects with design matrix $(n x q) Z$ and $u \sim N\left(O, \partial_{b}^{2} I\right)$; independent effects with equal variance

$e=$ residual errors $e \sim N\left(0, \partial^{2} \mathrm{I}\right)$ Knight [24]

\section{Results}

\subsection{Measure of Banana Damage Using Percentage Coefficient of Infestation}

Results indicated that farmers who used tissue culture planting materials if applying good husbandry practices had a mean PCI of $2.28 \% \pm 1.13$. Those who used ethnomedicinal products had a back transformed mean of $3.88 \% \pm 0.96$, which was lower than that for farmers who used synthetic chemicals. Farmers who used chemicals directly on the mat had an average PCI of $5.02 \% \pm 0.92$; those who applied chemicals on trap had highest PCI of $10.76 \% \pm 1.35$. This was higher than farmers who managed banana with good cultural practices only whose mean PCI stood at $6.71 \% \pm 1.15$ (Table 1).

The graph in Figure 1 indicated that farmers who used ethnomedicinal products, had a mean damage score that was less than for farmers who used synthetic chemicals on the mat or on traps. Farmers who used synthetic chemicals on trap had the highest score of weevil damage in their plantations. The score was higher than farmers who practiced good cultural practices. This may imply possibilities of resistance to synthetic chemicals by the banana weevils and/or poor methods of applying the chemicals as evidenced by the high
PCI of $10.76 \%$ by farmers who applied synthetic chemicals on traps. Development of resistance to synthetic chemicals may be attributed to the weak policy of importing agricultural drugs characterized by lack of surveillance to check quality of imports to the country and in drug stores. More in addition, according to Mcguigan et al., [25], there have been reports of adulteration of synthetic chemicals on Ugandan `market.

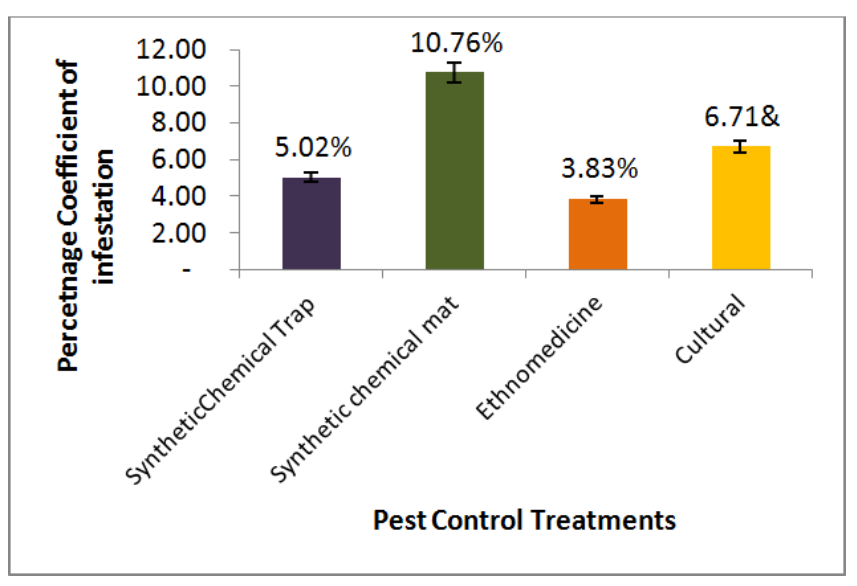

Figure 1. Banana weevil control treatments $n=$

The results also demonstrated that farmers, who used clean plating materials (tissue culture) with good cultural husbandry practices, may not require any other intervention to control banana weevils as they had the list damage score of $2.28 \% \pm 1.13$ in their banana plantations. Use of tissue culture as a source of clean planting material has been recommended by Uganda National Council for Science and Technology (UNCST) [26]. However, the outliers of $(+1.13)$ may signify that if routine management practices are not in place, weevils may as well multiply and equally damage the plants.

Fields where cultural practices were used properly, had a relatively low PCI though it was higher than where synthetic chemicals were used on mat but not statistically significantly different $(p=0.418)$. The finding was in agreement with Tinzaara et al., [27] research work in Lwengo, which established that cultural practices significantly reduced banana weevils below economic injury levels especially among smallholdings. According to Treverrow, Persley and Ireland, [28] weevil numbers may be kept low by digging out and removing old corms, trash and other materials in which weevils may breeds. De Graaf, Govender, Schoeman and Viljoen [29] had similar finding in South Africa.

The spread of damage among farmers who used ethnomedicinal products was slightly lower than where chemicals are used on mat. The farmers' fields where synthetic chemical were used had a high average percentage coefficient of infestation $(5.02 \pm 0.92 \%)$ in their gardens than farmers who used ethnomedicinal extracts with PCI of $(3.88 \%$. $\pm 096)$. This probably signifies that if ethnomedicinal products are used correctly they can help in management of banana pests especially among smallholder farmers.

\subsection{Statistical Analysis}


Table 1. Descriptive statistics on PIC in banana under different pest control treatments

\begin{tabular}{llllll}
\hline Treatment & N & Transformed Mean & Back-transformed mean & Std. Dev & Range \\
\hline Synthetic Chemicals on mat & 46 & 2.24 & 5.02 & \pm 0.92 & 3.88 \\
Synthetic Chemicals on trap & 31 & 3.28 & 10.76 & \pm 1.35 & 5.39 \\
Cultural & 77 & 2.59 & 6.71 & \pm 1.15 & 5.04 \\
Ethnomedicinal extracts & 69 & 1.97 & 3.88 & \pm 0.96 & 3.98 \\
Tissue culture (<3years) & 59 & 1.51 & 2.28 & \pm 1.13 & 5.06 \\
\hline
\end{tabular}

Table 2. Statistical analysis of Percentage Coefficient of Infestation (PCI) using REML

\begin{tabular}{llllll}
\hline Fixed term & Wald statistics & n.d.f & F statistics & d.d.f & F pr \\
\hline Treatment & 61.7 & 4 & 5.63 & 222 & $<0.001$ \\
Variety (CI) & 88.32 & 26 & 6.10 & 222 & 222 \\
$\begin{array}{l}\text { Treatment.CI } \\
\text { Dropping Terms from model }\end{array}$ & 30.6 & 29 & 1.30 & & 0.001 \\
Treatment.CI & 30.6 & 29 & 1.30 & 222 & \\
AIC & 268.12 & & BIC & 271.52 & 0.146 \\
\hline
\end{tabular}



Figure 1. Graph showing the Average Percentage Coefficient of Infestation of Banana under Different Pest Control Treatments (284)

To assess the statistical significance further analysis using REML was carried out. The data was tested for normality, linearity and homogeneity of variance. The data was found not be normal. According to Tinzaara et al., [27] before analysis data was transformed through a square root transformation to normalize it after adding a $0.5((\mathrm{x}+0.5) * 1 / 2$.).

However because data was spatially collected the treatment and varieties from which data was corrected were unbalanced. Therefore, use of ANOVA was not suitable and thus REML was applied. The various treatments (i.e. Ethnomedicinal extracts, synthetic chemicals cultural practice and use tissue culture) in factor "Treatment" and the different varieties in factor "Variety" were found to be statistically significant $(p=0.001)$. The interaction between variety and treatment with $(\mathrm{p}=0.146)$ was not significant (Table 2$)$.

Further analysis in REML was carried out to establish which of the varieties had the least damage and thus identify varieties that may be resistant to weevils. These could be tested further for their suitability for organic banana production. Results shows that (AAB) varieties "Nndizi" (Sweet banana), is the least affected by weevils and had the least percentage coefficient of infestation with the mean damage score of $0.89 \%$ (Figure 3). Among the cooking banana type, (AAA) varieties with the least mean (PCI) were: - "Ntike" (2.97\%), "Nsakala" (3.84\%), "Mpologoma"
(4.11\%), "Nakitembe" (4.12\%), "Nakawere" (4.47\%) and "Mbwazilume" (5.01\%). These were fairly resistant. The most affected in (AAA) varieties and in $(\mathrm{AAB})$ varieties were "Gonja" with a PCI score of (18.58\%); "Kisansa" (40.60\%), and "Kafuba" $(23.98 \%)$ but this need to be verified further. Results indicated that they are some varieties that express host resistance to banana weevils given the low PCI obtained from the selected sampled varieties. Improved varieties had a high host resistance as compared to the landrace varieties. This is in agreement with Reddy et al., [30]; Kiggundu [31] who reported that improved varieties expressed higher host resistance to banana weevils than the "Matooke" (AAA) type. The results of study were also in agreement with findings by Speijer et al., [32 but contradicted another study by Bagamba, Burger and Tushemereirwe [33] in which, "Gonja" was found to have higher survival rate than "Ndizi". Even when improved varieties had a high resistance to banana weevils, very few farmers planted them.

\section{Conclusions and Recommendations}

\subsection{Conclusion}

This study investigated the effectiveness of ethnomedicinal products used in control of banana weevils. It was intended to 
compare the percentage coefficient of infestation in plantation where ethnomedicinal products are used with plantations where they are not. This was in relation to the high loss of banana yields resulting from high infestation of banana weevils. The study specifically thought to compare the effectiveness of ethnomedicinal products with synthetic chemicals, cultural practices and banana planted from tissue culture. Based on the results of the PCI collected from various plantations, where different pest control products were used (ethnomedicinal products, cultural practices, synthetic chemicals and banana planted from tissue culture materials) and from earlier findings, it was established that there was no significant difference in damage caused by banana weevils between banana in fields where synthetic chemicals were applied and those banana in fields where ethnomedicinal extracts were applied (P-value $=0.678)$. Yet the mean difference of weevil damage in plantations where ethnomedicinal products were used was lower $(3.88 \%)$ than where chemicals were used $(5.02 \%)$. Since there was no significant difference in PCI where synthetic chemicals and ethnomedicinal were used $(\mathrm{P}$-value $=0.678)$. It can therefore, be concluded that ethnomedicinal products may equally be effective in management of banana weevils and can be recommended to be used by farmers to control banana weevils together with cultural control methods.

\subsection{Recommendation}

The study objective was about assessing the effectiveness of ethnomedicinal products in control of banana weevils. Owing to the fact that results of the study indicated positive signs of ethnomedicinal products being effective as compared to synthetic chemicals, further studies should be carried out to assess efficacy of the identified potential plants with pesticidal properties under controlled experiment. Also opportunities to explore these products on a commercial scale should be explored.

\section{Acknowledgement}

We acknowledge Regional University Forum for Capacity Building (RUFORUM) for sponsoring this research.

\section{References}

[1] FAO, 2002. The World Banana Economy, 1985-2002 Trade and Markets Division Washington DC ISBN: 9251050570

[2] Spilsbury J. Jagwe N. and Fernes R. SB., 2002. Evaluating the Marketing Opportunities of Banana and its Products in Principle Banana growing Countries; Food net and IITA.

[3] Bosch, C. Lorkeers A., Ndile M. R. and Sentozi E. 1995. Diagnostic survey: Constraints to banana productivity in Bukoba and Muleba Districts, Kagera region, Tanzania. Tanzania/Netherlands Farming Systems Research Project/ Lake Zone. Working Paper No. 8

[4] Katherine Killebrew and Hendrik Wolff 2010, Environmental Impacts of Agricultural Technologies EPAR Brief No. 65 Evans School Policy Analysis and Research (EPAR) of the Bill
\& Melinda Gates Foundation University of Washington

[5] Gold .S Clifford and Messiaen S, 2000. The Banana Weevil, Cosmopolites sordidus; Réseau International pour l'amélioration de la Banane et de la Banane Plantain, Parc Scientifique Agropolis II, 34397 Montpellier Cedex 5, FRANCE Tel : 33-(0)4 67611302 - Fax : 33-(0)4 67610334 - e-mail : inibap@cgiar.org - Internet : http://www inibap org. [Accessed 24/5/13]

[6] Philippe Tixier, Fabrice Vinatier, Juan Cabrera Cabrera, Ángeles Padilla Cubas, Justin Okolle, Christian Chabrier, Michel Guillon , 2010. Integrated Pest Management of black weevil in banana cropping systems; Cropping System Research Unit, CIRAD, and France.

[7] Adeleke Salami, Abdul B. Kamara and Zuzana Brixiova 2010 Smallholder Agriculture in East Africa: Trends, Constraints and Opportunities African Development Bank Angle des trois rues: Avenue du Ghana, Rue Pierre de Coubertin, Rue Hédi Nouira BP 323 -1002 TUNIS belvédère (Tunisia)

[8] Mugisha-Kamatenesi M, Deng A, Ogendo J, Omolo E, Mihale M, Otim M, Buyungo J, Bett P (2008). Indigenous knowledge of field insectpests and their management around Lake Victoria Basin in Uganda. Afr. J. Environ. Science and Technology

[9] Berger Amalie, 1994. Twice Humanity: Implications to local and Global Resource Use. Nordiska Africainstitutet, Uppsala Forum for Development Studies, Uppsala University, ISBN $917106415 \mathrm{X}$

[10] Joy. P.P, Thomas J, Mathew S. and Shakaria, 1998. Medicinal Plants Kerala, Agricultural University Kerala.

[11] Inyanga .U.E and Emosarie, 2005. Laboratory assessment of Repellent and Anti feedants Properties of Aqueous Extracts of Plants against Banana weevils; Dept of Crop Science University of Uyo, Nigeria .V.C.

[12] Musabyimana, 1999. Neem Seed Management of Banana Weevils, Cosmopolites sordidus (Germar) and Banana Parasitic Nematodes Complex, PHD Thesis Kenyatta University, Nairobi.

[13] Umeh, D. Onukwu, Adebowale E.M. and Thomas J., 2010. Wohlgemuth Control Options for Banana Weevil (Cosmopolites sordidus) and Termites (Microtermes spp.) on Banana and Plantain (Musa spp.) Nigeria National Horticultural Research Institute, Jericho Reservation Area: P.M.B. 5432, Idi-Ishin, Ibadan, Nigeria

[14] Mwine, Julius, P. Vandamme, G. Kamoga and F. Jumba (2010). Ethnobotanical Surveys of pesticidal plants Used in southern Uganda: A case study of Masaka; Journal of Medicinal Plant Research Volume 5. http://www.academicjournal.org/jmpr [ accessed on 27/02/13]

[15] Suman Bukka, Sailaja and Thuaga Raju, 2011. The study of Morphology, Phytochemical and Pharmacological Aspects of Rhinacathus nasistus (L) King (A review). Journal of Applied Pharmatical Science http//www.japsoline.com [Accessed $19 / 6 / 13]$

[16] Anand Prakash, Jagadiswari Rao and Nandagopal V. 2008. Future of botanical pesticides in rice, wheat, pulses and vegetables pest management. Journal of Biopesticide

[17] Patterson, H.D. and Thompson, R. (1971). Recovery of inter-block information when block sizes are unequal. Biometrika, 
[18] Welham Sue 2008. Restricted Maximum Likelihood Estimation and Linear Mixed Models. Rothamsted Research, Harpenden UK- AL5-2JQS

[19] Benjamin M. Bolker,1 Mollie E. Brooks1, Connie J. Clark1, Shane W. Geange2, John R. Poulsen1, M. Henry H. Stevens3 and Jada-Simone S. White, 2009 Generalized Linear Mixed Models: A Practical Guide for Ecology and Evolution 1.Department of Botany and Zoology, University of Florida, PO Box 118525, Gainesville, FL 32611-8525, USA;

[20] Smith G. K. and Verbyla A. P., 1996. A Conditional Approach to Residual Maximum Likelihood Estimation in Generalized Linear Models. Journal of the Royal Statistical Society, Australia

[21] Ross Kenneth N. 2003. Sample Design for Educational Survey Research, International Institute for Educational Planning/UNESCO 7-9 rue Eugène-Delacroix, 75116 Paris, France

[22] Oginga Latigo and Bakyalire, 1993. Use of Pseudo stems and Percentage Coefficient of Infestation and Damage by Cosmopolites Sordidus (Germar), Department of Crop Science, Makerere University, P.O Box7002 Kampala, Uganda.

[23] Gold S. Clifford, 2001. Biology and Integrated Pest Management of Banana Weevils Cosmopolites sordidus (Germar). Advancing Banana Plantain Research and Development in Asia and Pacific Vol. 10 INABP-ASPNNET, Los Bons.

[24] Knight Emma, 2008. Improved Iterative Schemes for REML Estimation of Variance Parameters in Linear Mixed Models. School of Agriculture, Food and Wine, the University of Adelaide.

[25] Macguigan Claire, Zake Fred, Luswata-Kibanda David, Nyabuntu and Semwanga James, 2005. Developing and Promoting Principles for the Ugandan Agro Business Sector: Business Service Market Development, Department for International Development (DFID) and International Labour Organisation (ILO).

[26] Uganda National Council for Science and Technology (UNCST), 2007 The biology of bananas and plantains PBS US Agency for International Development (USAID) funded Project

[27] Tiinzara. W, A. Barekye, Gold Clifford, Nankinga Caroline,
Kagezi Godfrey, Ragana R., Tushemererwe W. and Blomme G., 2003. Effect of Cultural Practices, Biorationals and Neem on Banana weevils and Nematodes in Masaka District, Uganda: INBAP (IITA) Kampala, Uganda. Cedex 5, FRANCE Tel: 33-(0)4 $6761 \quad 1302$ - Fax: 33-(0)4 67610334 E-mail : inibap@cgiar.org - Internet : http://www.inibap.org . [Accessed 24/5/13]

[28] Treverrow N., Peasley D., Ireland G., 1992. Banana weevil borer, a pest management handbook for banana growers. Banana Industry Committee, New South Wales Agriculture, NSW, Australia.

[29] De Graaf ${ }^{1}$ J., P. Govender ${ }^{2}$, A. S. Schoeman ${ }^{2}$, A. Viljoen ${ }^{3}$ (2008) Efficacy of cultural control measures against the banana weevil, Cosmopolites sordidus (Germar), in South Africa Journal of Applied Entomology Volume 132, Issue 1

[30] Reddy Sesh, Ngonde Sssenyonga.J.W, Waludde M.W, Onyango M.,Ngoza S, Adede T.O, 1998. Management of Banana pests and Disease in Kenya, Status Report: Mobilising IPM for Sustainable Banana Production in Africa Conference Preceding in Nelspruit, 1998 INIBAP, Montpellier, 1999 ISBN -2-9108 10-33.

[31] Kiggundu A., 2000. Host Plant Reaction and Resistance Mechanism to Banana Weevils, Cosmopolites Sordidus (Germar) in Uganda Germplasm , Orange state University South Africa.

[32] Speijer, P.R., Gold, C.S., Karamura, E.B. and Kashaija, I.N. 1994. Banana weevil and Nematode distribution patterns in highland systems in Uganda: preliminary results from a diagnostic survey. African Crop Science Conference Proceedings. ACSS,Kampala.

[33] Peasely D.1. and Trevellow N. (1985) Count and Dry : a Banana Weevil Borer Management Program

[34] Bagamba F. 1, 3, Burger K. 2 and Tushemereirwe W.K1. Banana (Musa spp.) Production Characteristics and Performance in Uganda.

[35] 1. National Banana Research Programme, Kawanda, National Agricultural Research Organization (NARO), P.O. Box 7065, Kampala, Uganda.

[36] 2. Development Economics Leeuwenborch Hollandseweg 1 $6706 \mathrm{KN}$ Wagennigen, the Netherlands; 3Current Address: Makerere University, P.O. Box 7062, Kampala, Uganda 